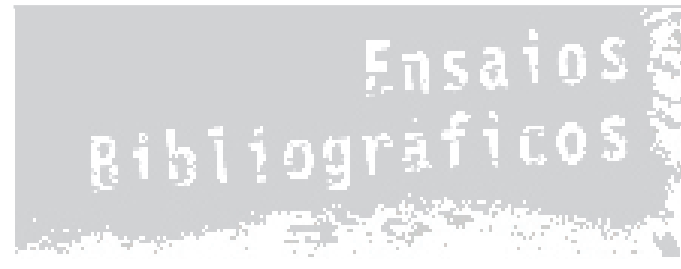

\title{
Mário de Andrade: Turista aprendiz da musicalidade brasileira
}

\section{Carla Delgado de Souza IN TR O DUÇÃ O}

(UNICAMP)

Já afirmei que não sou folclorista. O folclore é uma ciência, dizem... Me interesso pela ciência, porém não tenho capacidade para ser cientista. Minha intenção é fornecer documentação prá músico e não passar vinte anos escrevendo sobre a expressão fisionômica do lagarto. Mário de Andrade, 1927.

Em 1928 - logo após retornar de sua primeira viagem ao Norte do Brasil, que, segundo a fala de Mário de Andrade acima citada, tinha fins unicamente pragmáticos - o famoso escritor modernista publicou um dos livros de maior envergadura no campo da Musicologia nacional. Trata-se do famoso Ensaio sobre a música brasileira, obra que foi considerada leitura "obrigatória" para todos os músicos atuantes no cenário nacional por ao menos três décadas. O livro, que se constituiu como um manual de orientação composicional no campo da música erudita brasileira, traz diversos exemplos musicais colhidos tanto por seu autor, quanto por alguns folcloristas brasileiros. O intuito de Mário de Andrade, ao transcrever sonoridades folclóricas em seu livro sobre música brasileira, era o de proporcionar material do folclore musical brasileiro aos compositores, pois, de acordo com o pensamento estético de Mário de Andrade, era necessário que os artistas brasileiros atuassem de forma a construir uma música que fosse eminentemente nacional.

Durante o período que se inicia na década de 1920 e prossegue pelo menos até 1960 , a produção musical no Brasil esteve fortemente vinculada a uma orientação estética nacionalista. A idéia, apesar de não ser nova (desde o Romantismo havia o desejo artístico de representar o Brasil por meio das artes desenvolvidas em território nacional), é reformulada durante o Modernismo, época em que os artistas advogam que a arte nacional deveria procurar elementos estéticos autóctones de expressão. Inicialmente concebida como uma revolução meramente formal e estética, a orientação nacionalista apregoada pelos artistas modernistas colocou o Brasil e a cultura brasileira 
na pauta das discussões políticas e sociais. Esse movimento conseguiu, inclusive, ter uma rotinização política que foi alvo de vários estudos clássicos do pensamento social brasileiro, como, por exemplo, os desenvolvidos por Candido (1983), Miceli (1979) e Velloso (1987), entre outros.

Apesar de o período acima destacado ter sido bastante estudado por cientistas sociais, a importância localizada que uma produção específica, o Ensaio sobre a música brasileira, teve para a reconfiguração da arte musical nacional ainda não foi devidamente ressaltada no campo da Antropologia Social. Sendo um livro escrito para músicos, seu destino foi aquele designado por seu autor: constituir um guia de cultura e sonoridades brasileiras para orientar a composição musical erudita no Brasil. Com uma teoria estética bastante clara acerca de qual é o papel da arte brasileira durante os anos 1920 e 1930, esse livro parece ter condensado uma série de prerrogativas que tinham o intuito de fundamentar os preceitos básicos e essenciais acerca do que seria a "verdadeira" música nacionalista brasileira.

Não é, contudo, meu interesse abarcar aqui o real alcance que a teoria artística marioandradiana teve no desenvolvimento da música erudita brasileira. Para isso, seria necessária a realização de uma pesquisa pormenorizada que explicitasse as relações entre as composições dos chamados compositores filiados à estética nacionalista com as prerrogativas escritas por Mário de Andrade. Embora essa seja uma pesquisa interessante, o presente ensaio tem outra ambição: demonstrar como a produção dessa obra, o Ensaio sobre a música brasileira, está vinculada a um processo de descobrimento sonoro do Brasil, que foi catalisado pela viagem que seu autor fez à região Norte do país em 1927, além de mostrar como a experiência da escrita de seu livro sobre a música brasileira o influenciou a seguir viagem para o Nordeste em fins de 1928 e início de 1929.

Se tomarmos como ponto de saída a declaração proferida por Mário de Andrade, citada como epígrafe deste texto, podemos entender os intuitos do escritor, também professor de História da música no Conservatório Dramático Musical de São Paulo, quando ele se aventurou a conhecer os segredos da musicalidade nortista, por meio da viagem a essa região do Brasil que realiza em 13 de maio de 1927. Os propósitos de seus estudos musicológicos em muito se distanciavam da caracterização que ele mesmo fazia de um folclorista. Como o autor afirmou, sua intenção era prática, na medida em que ele desejava apenas nutrir os músicos brasileiros (em especial os compositores) de elementos próprios da cultura brasileira, que, segundo o próprio Mário de Andrade, eram o substrato sob o qual deveria se desenvolver toda a produção artística do país.

Negando veementemente a alcunha de folclorista, Mário de Andrade explicitou que sua dedicação ao estudo do folclore musical se realizava de forma a recolher um material sonoro que era fundamental para o avanço da música brasileira. Nada tinha, portanto, de folclorista, cientista ou etnógrafo. Contudo, algo ocorre em seu percurso que faz com que a noção de musicalidade e até mesmo as concepções de pesquisa musicológica do escritor se alterassem sensivelmente. De pessoa alheia aos interesses científicos do trabalho de campo, Mário de Andrade se converteu, em apenas nove anos, em um dos nomes mais importantes no que se refere à fundação da Sociedade de Etnografia e Folclore, em São Paulo ${ }^{1}$. Como e por que ocorreu essa transformação? De fato, as viagens que Mário de Andrade fez aos interiores do Brasil tem uma profunda importância no que se refere à transformação de 
sua concepção de pesquisa musicológica.

Em seu estudo sobre Maurice Leenhardt, James Clifford (1982) mostrou como este missionário protestante converteu-se em antropólogo quando partiu para a Melanésia. Para isso, escreveu a biografia de Leenhardt de forma a mostrar como a experiência do missionário francês junto aos melanésios alterou significativamente a própria história de vida desse protagonista. Fruto de sua experiência social junto aos melanésios, a própria perspectiva de Leenhardt sobre o mundo que o cercava foi alterada, à medida em que, ao invés de promover a cristianização dos melanésios, acabou sendo convertido por eles em antropólogo. Guardadas as devidas proporções - nem Mário de Andrade transformou-se em etnógrafo, nem eu faço a biografia dele neste ensaio - essa evocação faz sentido à medida que é boa para pensar como as viagens, sobretudo aquelas que proporcionam um convívio intenso com a alteridade, são meios de redefinição da experiência social de alguns sujeitos.

Vale lembrar que a retórica das viagens de descobrimento dos sertões e rincões brasileiros era bastante valorizada na época em que Mário de Andrade decidiu se aventurar a descobrir sonoramente o Norte brasileiro. Basta atentarmos as trajetórias de vários artistas e intelectuais brasileiros do momento para perceber que, tão importante quanto as viagens à Europa para a atualização estética dessas pessoas, eram as viagens de conhecimento da "cultura rústica" brasileira. Exemplar, nesse sentido, é o uso que o compositor Heitor Villa-Lobos faz das viagens que ele fez pelo Brasil, sobretudo à Amazônia, na configuração de sua música. O fato de ter estado entre os índios e de ter conhecido a floresta brasileira conferiu a ele a autoridade artística necessária para se tornar um dos maiores representantes da música erudita brasileira, tanto em termos nacionais, quanto no exterior. Muito embora vários autores questionem a veracidade das histórias villalobianas acerca de sua experiência como viajante ${ }^{2}$, era evidente o quanto as anedotas contadas pelo compositor agradavam ao público nacional e estrangeiro e foram fundamentais para a constituição de sua trajetória enquanto um artista conhecedor das sonoridades brasileiras e do folclore musical nacional.

Era importante, portanto, que Mário de Andrade se dedicasse a conhecer devidamente esse folclore musical para poder legitimar sua posição enquanto artista brasileiro e teórico da música nacional. No entanto, por mais que suas pesquisas musicológicas tenham se iniciado sem nenhum respaldo "científico" ou "etnográfico" e tivessem uma finalidade exclusivamente pragmática, é fato que com o passar dos anos essa realidade mudou significativamente. Se, antes, a expedição ao Norte era, para ele, algo extremamente doloroso ${ }^{3}$ a ser feito e tinha o intuito meramente de munir os músicos brasileiros de material sonoro para suas composições nacionais, após as viagens de 1927 e 1929 ao Norte e Nordeste do Brasil, Mário de Andrade buscou se informar sobre as pesquisas etnomusicológicas que vinham sendo desenvolvidas e publicadas mundialmente.

Segundo Toni (1990), o trabalho de documentação da musicalidade popular e folclórica que Mário de Andrade se dispôs a desenvolver não era uma tarefa simples para alguém que, como ele, tinha um aprendizado formal em música que era incapaz de supri-lo de conhecimentos necessários ao trabalho de campo de coleta de temas e melodias folclóricas. Não é à toa, portanto, que Mário de Andrade iniciou suas leituras de musicologia comparada (como era chamada a etnomusicologia àquela época) em 1929. Dentre os textos lidos, estavam os trabalhos de 
Raoul e Marguerite D'Harcourt e de Roquete Pinto, além de Esquisse d'une methode de folklore musical, escrito por Constantin Brailoiu.

Partindo dessa questão inicial acerca de como Mário de Andrade se transformou, em tão pouco tempo, de um homem avesso à cientificidade etnográfica em um dos nomes essenciais para a fundação da Sociedade de Etnografia e Folclore, o presente artigo tem como objetivo mostrar como a concepção de musicalidade do escritor se alterou significativamente durante seu trabalho de campo entre várias populações nortistas que conheceu em 1927, assim como de ressaltar os usos do folclore musical para a constituição da música nacionalista no interior da teoria estética marioandradiana.

Sem dúvida alguma Mário de Andrade foi um dos intelectuais, de perfil profundamente erudito, que mais marcou a história do pensamento social brasileiro. Altamente conectado com todas as produções literárias e artísticas desde o limiar da década de 1920 até o momento de sua morte, é fato incontestável o seu trânsito em meio a todas as obras de cunho modernista: as amizades com Carlos Drummond de Andrade, Manuel Bandeira, Câmara Cascudo, Anita Malfati, Tarsila do Amaral, Heitor Villa-Lobos e Camargo Guarnieri, entre outras, são exemplos categóricos das várias faces que compunham seu caráter ímpar, sobretudo enquanto teórico de uma estética modernista e nacional.

Apesar de, como exposto acima, podermos verificar uma extrema versatilidade de preocupações estéticas no interior das produções e atuações do intelectual paulistano, é essencial explorar o papel primordial que a música ocupou, tanto na estrutura lógica de seu pensamento, quanto nas designações a ela referidas em meio ao projeto modernista de "construção da nacionalidade brasileira". A paixão confessa pela música e o seu início de carreira intrinsecamente ligado aos estudos musicais e à sua condição de professor, ainda que inicialmente substituto, da cátedra de "História da Arte" do "Conservatório Dramático e Musical de São Paulo" influenciaram diretamente a concepção marcadamente européia de musicalidade do escritor. Contudo, a exigência trazida por sua própria idéia de atitude estética, a qual deveria buscar nas "fontes legítimas" do folclore brasileiro os símbolos da "verdadeira cultura nacional", acabou por relativizar e suavizar os ditames do universo musical dentre o qual ele foi formado culturalmente.

Segundo Toni (1990), Mário de Andrade iniciou seus estudos de piano no Conservatório Dramático Musical de São Paulo em 1911, quando já contava com 18 anos de idade. Se, por um lado, começou seus estudos formais de instrumento tardiamente (comparativamente a idade média que os aprendizes de piano iniciam os cursos nas instituições de ensino musical), por outro, os conhecimentos prévios de música do jovem estudante parecem ter sido fundamentais para que, apenas dois anos depois, ele já assumisse, como professor substituto, a cátedra de História da Música dessa mesma instituição, nela se formando em 1918. 
Nesse período, a música brasileira já era pautada por uma lógica que atrelava, de certa forma, algumas temáticas nacionais a uma sonoridade marcadamente italiana. Um exemplo notório desse híbrido casamento pode ser vislumbrado por meio da ópera $O$ Guarani, do compositor Carlos Gomes, que, sendo inclusive cantada em italiano, baseou-se no romance homônimo de José de Alencar, que retratava o amor de um índio (Peri) por uma branca (Ceci). Nela, a temática era nacional, além de o libreto se basear em um livro importante da literatura brasileira. Contudo, a música, meio de expressão maior num espetáculo operístico, era caracterizada pela sonoridade italiana.

Durante todo o século XIX, a música italiana foi preponderante não apenas no cenário nacional, mas também na Europa. Esse cenário, no entanto, começava a mudar no início do século XX, sobretudo no Rio de Janeiro, que, contando com a presença de Alberto Nepomuceno frente à direção do Conservatório Nacional, já se abria a diversas contribuições da música impressionista francesa. Contudo, em São Paulo, essas mudanças tardariam mais a acontecer, uma vez que o quadro docente do conservatório mais importante da cidade, onde Mário estudou, era formado por professores ligados à estética romântica italiana ${ }^{4}$.

Foi somente a partir de 1922, provavelmente a partir do encontro com Heitor Villa-Lobos e sua música, que se deu durante a Semana de Arte Moderna de 1922, que Mário de Andrade atentou para o "provincianismo" da música ensinada em São Paulo. Como personagens atuantes nesse meio, escritor e compositor começaram um prolífico diálogo sobre música brasileira e construção da arte brasileira, que seria interrompido bruscamente nos anos 1930, ao que tudo indica, por conta da atuação de Heitor Villa-Lobos frente ao projeto pedagógico musical do canto orfeônico, uma das vitrines culturais do governo Vargas, de quem Mário era opositor ${ }^{5}$.

Velloso (1987) aponta que a partir da década de 1920, além da busca dos ideais exclusivamente estéticos, os intelectuais passaram a se defrontar com as problemáticas e as diversidades sociais brasileiras, dadas especialmente nos campos sócio-econômico e educativo. Os artistas de inspiração modernista buscavam as raízes da construção de nossa nacionalidade e atentavam-se, sobretudo, em veiculá-los através de suas manifestações artísticas. Neste sentido, os intelectuais, em um sentido mais geral, se autoproclamavam a "consciência iluminada do nacional", responsável pelo desenvolvimento do Brasil, através de políticas artísticas e pedagógicas que fossem capazes de acelerar o nosso "processo civilizatório".

No caso da música, a maior mudança refere-se a incorporação de sonoridades ameríndias, africanas e européias que, após um tratamento estético moderno, conferido pelo compositor, seriam capazes de expressar a "verdadeira" música brasileira. Diferenciando-se da cópia dos modelos musicais europeus, a nova música brasileira deveria trazer elementos novos para o patrimônio cultural da humanidade, ao mesmo tempo em que estaria de acordo com os ditames e padrões estéticos praticados no momento. Como bem pontuou Travassos (1997), esse movimento de incorporação de elementos locais e nacionais em uma música ocidental com pretensões universais não é exclusivo do contexto brasileiro. Tanto isso é verdade que várias pesquisas de coleta de temas folclóricos foram desenvolvidas por Béla Bartók e por Zoltán Kódaly, na Hungria, também nas primeiras décadas do século XX.

De acordo com Moraes (1999), as questões referentes à estética musical estiveram presentes no interior do pensamento de Mário de Andrade desde os primeiros anos da década de 1920, sendo que tais reflexões só 
alcançaram um aprofundamento e uma sistematização racional visíveis a partir da publicação da primeira obra que escreve centrando-se na discussão a respeito da conformação do caráter da música nacionalista brasileira - $O$ Ensaio sobre a Música Brasileira, de 1928. Segundo Toni (1990) é a partir desse fato que Mário de Andrade começou a expor de forma mais clara sua predileção pela música enquanto elemento artístico privilegiado da vida cultural das sociedades humanas, e mais precisamente ainda, da sociedade brasileira.

Publicando obras musicais intensamente até $1935^{6}$, Mário de Andrade já delineou de forma precisa suas argumentações centrais quanto aos aspectos primordiais de sua teoria estética em seu primeiro livro musical, de 1928. Já nesta obra Mário de Andrade afirmava o caráter eminentemente social das criações artísticas, o que já legitimava a importância de o artista estar em conformidade com o seu tempo e com sua sociedade. A aversão a todo tipo de formalismo e individualismo musicais também já se fazia presente, sendo, contudo, acentuada posteriormente em seu "Compendio sobre a História da Música", datado originalmente de 1929 e depois publicado com o Título de Pequena História da Música (Travassos 1997).

Os postulados e as afirmativas de O Ensaio sobre a Música Brasileira, no entanto, só podem ser compreendidos à medida que considerarmos seu momento de escrita e de publicação, já que a primeira edição desta sua obra se dá em meio a duas viagens que o autor realizou ao Norte e Nordeste do país, relatadas posteriormente em seu diário de viagens, publicado com o título O Turista Aprendiz, em 1943. Segundo Lopez (1996) Mário de Andrade realizou algumas viagens "etnográficas", as quais possuíram a pretensão do poeta em conhecer mais fielmente o interior de seu próprio país, para, a partir desse conhecimento, poder criar de forma eminentemente nacional. As duas primeiras viagens que fez destinaram-se ao interior do estado de Minas Gerais, sendo a primeira datada de 1919, às cidades históricas mineiras. Nessa primeira viagem Mário teve um contato impactante com as obras de Aleijadinho e com o barroco mineiro, expressões artísticas que mais tarde chegaria a considerar como as de maior relevância no contexto de produção nacional e nacionalista no contexto cultural brasileiro (Simões Júnior 1998).

A segunda viagem de cunho mais propriamente etnográfico que realizou data de 1924, ano determinante para a pauta modernista, sendo que esta ele a fez acompanhado por intelectuais, como Blaise Cendrars (que estava de passagem pelo Brasil), Tarsila do Amaral, Oswald de Andrade, Nonê (filho de Oswald), D. Olívia Guedes Penteado, Paulo Prado, René Thiollier e Gofredo da Silva Telles, que posteriormente se designariam como a "caravana paulista". Na verdade, essa viagem foi essencial para Mário de Andrade, que a denominou como: "viagem de descoberta do Brasil", uma vez que o contato próximo com a população mineira propiciou o tão esperado encontro com uma determinada "cultura rústica", dotada de uma atmosfera, mesmo que dinâmica, de "autenticidade cultural". (Lopez 2002).

A partir dessa experiência, que provocou um amadurecimento visível em meio ao projeto modernista traçado tanto por Oswald - que publicou o "Manifesto Pau Brasil” neste mesmo ano de 1924 - quanto por Mário, que teve 
sua produção poética concentrada em “Clã do Jaboti” (obra que refletiu uma consciência de Brasil que se vinculou mais a uma proposta crítica, iluminada por soluções e técnicas específicas da cultura popular mineira), a "caravana da descoberta do Brasil" pretendia partir novamente, agora rumo à Amazônia. No entanto, no momento da partida, Mário de Andrade se desiludiu ao saber que viajaria acompanhado apenas por D. Olívia Guedes Penteado e sua sobrinha Margarida Guedes Nogueira, além de Dulce do Amaral Pinto, filha de Tarsila. Mesmo assim, hesitante, entrou no vapor Pedro I e enfrentou seu projeto.

A viagem à Amazônia, a julgar pelos textos de 1927 e 1928 que dela resultaram, foi claramente marcada pela preocupação etnográfica, com Mário de Andrade procurando entender uma particularidade do Brasil através da observação da vida do povo. Ela teria também lhe mostrado a necessidade de por logo em prática seu velho projeto de visita ao Nordeste, desejando agora realizar uma pesquisa mais sistemática em uma região que se oferecia tão rica em tradição musical popular (Lopez 2002: 19).

O perfil de Mário, enquanto pesquisador, precisa, no entanto, ser melhor delineado, uma vez que este afirmou diversas vezes de que ele deveria estar, a todo instante, a serviço da ação, de forma que a pesquisa musical que ele realizou somente faria sentido quando fosse aplicada nas composições e interpretações dos músicos. O caráter missionário da pesquisa sobre o universo musical popular fica ainda mais evidente quando tomamos esse trecho do texto de Flávia Toni:

Assim, Mário preconiza que o conhecimento deve ter como objetivo imediato uma ação que, no caso dele, equivale à divulgação dos objetos que lhes são caros, motivo que o leva a admitir um tanto de pragmatismo. Ou seja, o saber requisita um diálogo democrático entre a apreensão do dado popular, sua análise e conseqüente transmissão aos que possam desfruta-lo. Foi assim com o Ensaio, com as Modinhas Imperiais, o "Romance do Veludo", e o planejado para aqueles títulos de 1929 (Toni 1990: 15).

Como já foi dito anteriormente, a formação estético-musical de Mário de Andrade foi marcadamente ligada à concepção veiculada pelo universo erudito das produções musicais das academias européias, principalmente a italiana. De certa forma, o descentramento cultural provocado pelo contato com outras fontes da cultura brasileira, como a sertaneja e a amazônica, fez com que Mário de Andrade atentasse para a diversidade cultural, expressa em particularidades de vocabulário, de vestimenta e de sonoridade, entre outras coisas, que o levaram a constatar a insuficiência da linguagem intelectual paulistana, assim como da musicalidade codificada em partituras, segundo os modelos ocidentais de escrita musical, para a compreensão do Brasil e de determinados ideais de brasilidade.

Como era de se esperar, os trechos citados no Ensaio sobre a música brasileira são citados sem nenhuma correlação com a situação no qual eram evocados. Além disso, a não preocupação de Mário de Andrade em recolher esses cânticos nos momentos festivos ou rituais em que eles apareciam evidencia certo descompasso 
de como ele realizava suas pesquisas em relação a como os etnomusicólogos com formação científica realizavam suas coletas de material sonoro nessa época.

Mesmo assim, esse conhecimento de sonoridades nortistas foi criador também em termos literários: a partir dele, Mário recorreu à ficção e à inventividade para criar imaginariamente dois povos amazônicos, os quais teria tido contato em sua primeira viagem ao Norte do país. Ambas as sociedades indígenas, por ele inventadas e caracterizadas, eram fundamentalmente marcadas pelas diferenças, sobretudo sonoras, que apresentavam e consolidavam socialmente. Segundo Lopez (2002), a criação ficcional, muito mais presente nos relatos do primeiro diário de "O Turista Aprendiz", é fator imprescindível para que possamos compreender a finalidade artística do escritor, que, baseado no arte-fazer, buscava permear seu diário de viagens com elementos descritivos de uma situação real e com relatos, mais parecidos com contos (sobretudo quanto a sua afeição ao insólito e ao mágico), que na verdade expressam a trans-viagem de criação artística que ele realizou, evidente nos episódios referentes à “Tribo dos Pacáas Novos" e aos “Índios Dó-Mi-Sol” (Lopez 1996).

Mário, modernista e também nacionalista, fará ficção a partir da própria realidade experimentada ou observada, fazendo questão de explorá-la em dois aspectos: o real, e o ficcional, partindo desse mesmo real. Nesse sentido, é bastante auxiliado por sua concepção de realidade sul americana, uma vez que, instrumentado pelo senso crítico, consegue entender que, dentro de uma ótica européia, marcada pelo racionalismo, acostumada a um mundo tecnizado, nossa realidade seria o maravilhoso instaurado em sua peculiaridade, sensível a uma abordagem surrealista, que procura denunciar a impropriedade dessa mesma ótica. O maravilhoso possibilita o autor trabalhar com a narração, evitando a descrição do já repetido e reiterado. Percebendo a hipérbole como elemento constitutivo da paisagem e da própria vida da região, evita-a em sua linguagem, transformando-a no insólito narrativo (Lopez 2000: 40).

$\mathrm{Na}$ "Tribo dos Pacáas Novos", Mário de Andrade revela o valor sagrado ou profano de tudo o que de certa forma é sonoro. Inclusive a comunicação destes indígenas é realizada de maneira completamente diversa: ao invés da utilização de fonemas e suas articulações na formação de palavras e de um sistema lingüístico propriamente, os pacáas comunicavam-se quase que exclusivamente com movimentos corporais. Mário, ao relatar sua história nos fala da presença imprescindível de um velho que se tornou seu tradutor entre a linguagem foneticamente organizada, que ele possuía, e a linguagem expressivamente corporal da qual compartilhavam tais índios. Também percebe, pela caracterização das "vestimentas" dos adultos, que há uma noção muito peculiar entre o que no corpo é o "vergonhoso". Para os pacáas as orelhas e os narizes, no limite, são as partes mais íntimas do corpo, fato visível através da vestimenta que adotavam publicamente: nela toda a cabeça, tanto de homens quanto de mulheres, era duplamente coberta, sendo só os olhos revelados. Essa passagem do texto "O Turista Aprendiz", de Mário de Andrade, demonstra perfeitamente isso: 
não mostráveis dos corpos não são as que a gente consideramos assim. (...). Consideram o nariz e as orelhas, as partes mais vergonhosas do corpo, que não se deve mostrar a ninguém, nem pros pais, só marido e mulher na mais rigorosa intimidade. Escutar, pra eles, é o que chamamos de pecado mortal. Falar pra eles é o máximo gesto sexual"(Andrade 2002: 85-86).

Segundo a interpretação de Flávia Toni (1990), é nesse momento que, de forma extremamente criativa, Mário relatou o fato de ter perdido sua virgindade auditiva, ou seja, foi no contato estabelecido com os Pacáas Novos que ele se conscientizou da existência de relações diferenciadas com a sonoridade de acordo com cada povo, ou melhor, estabelecida em concordância com cada sociabilidade em questão. Essa descoberta é fundamental para que o pesquisador musical Mário de Andrade compreenda a música como produto social, afirmação expressa em seu livro "Ensaio sobre a Música Brasileira". Além disso, a busca por uma música nacionalista deve perpassar essa reflexão, bem como a incorporação de aspectos sonoros presentes em nossa natureza e em nosso folclore musical, ainda muito desconhecido, no interior das composições.

No entanto, a diversidade de escalas musicais e intervalos possíveis só foi evidenciada quando Mário se debruçou a narrar a segunda sociedade ameríndia que também é fruto de sua criação intelectual e que reflete, assim como a "Tribo dos Pacáas Novos", as indagações e percepções referentes a novos universos sonoros ainda não existentes para o professor do Conservatório Dramático Musical de São Paulo, vinculado anteriormente a apenas uma possibilidade de percepção sonora.

Ao relatar, em seis episódios de seu livro "O Turista Aprendiz", a sociabilidade intrinsecamente musical dos "Índios Dó-Mi-Sol”, o autor exalta o produto musical em detrimento da própria palavra. Para esses índios, mais importante até que o que de fato pronunciam é como o fazem: tanto de acordo com a intensidade musical (pianíssimo, piano, forte, fortíssimo) como em relação ao andamento crescente ou minguante da entonação, assim como, por fim, se o que é pronunciado corresponde a um intervalo ascendente (portanto, revelando uma idéia de positividade e aceitação) ou a um intervalo descendente(revelando a negação e a indignação por parte do "falante/ cantor"). Essa sociedade dos "Índios Dó-Mi-Sol" foi considerada por Mário como mais avançada do que qualquer uma das outras sociedades humanas, geralmente pautada em uma comunicação fonética ou corporal, como no caso da "Tribo dos Pacáas Novos". 
O período atual do Brasil, especialmente nas artes, é o de nacionalização. Estamos procurando conformar a produção humana do país com a realidade nacional. E é nessa ordem de idéias que justifica-se o conceito de primitivismo aplicado às orientações de agora. É um engano imaginar que o primitivismo brasileiro de hoje é estético. Ele é social (...).Pois toda arte socialmente primitiva que nem a nossa é arte social, tribal, religiosa, comemorativa. É arte de circunstância. É interessada. Toda arte exclusivamente artística e desinteressada não tem cabimento numa fase primitiva, fase de construção. $\dot{E}$ intrinsecamente individualista. $E$ os efeitos do individualismo artístico no geral são destrutivos.

Mário de Andrade $1928^{8}$.

Já de volta a São Paulo da primeira viagem realizada à região amazônica, Mário de Andrade publicou seu Ensaio sobre a música brasileira. O trecho acima é parte do livro e exprime de maneira bem sucinta os motivos pelos quais Mário de Andrade estava se dedicando à defesa de uma arte que fosse nacional. Mas o que era essa arte nacional para Mário de Andrade? Como essa música deveria se expressar?

Segundo o pensamento marioandradiano, a música nacional não poderia conter exotismos e nem estrangeirismos, além de ter que expressar o inconsciente musical brasileiro, miscigenado por definição. Sendo assim, a música brasileira não deveria ser uma mera colagem de sonoridades ora ameríndias, ora africanas, ou então portuguesas. Mais do que isso, ela deveria ser o resultado de como essa mistura étnica se manifestava sonoramente. É interessante notar, nesse aspecto, a força do mito fundador do Brasil para a definição do ser nacional na teoria estético-musical de Mário de Andrade.

Importantíssima, também, era a defesa que ele fazia acerca do caráter social da arte, que tinha como finalidade a elaboração de uma estética que conseguisse reunir as várias manifestações artísticas brasileiras para a configuração de uma unidade artística, podendo assim atribuir um caráter nacional à cultura e à sociedade brasileira. Portanto, esse ideal artístico proposto, diretamente vinculado à vida social da qual emergia, possuía compromissos visíveis para com a atualidade de sua produção, bem como para com a função social a ser desempenhada pelas artes nos primeiros decênios do século XX. Chamada de música interessada, a música nacionalista era a única que importava para o Brasil, que ainda estava se constituindo enquanto nação. Nesse sentido, para Mário de Andrade é justamente por pertencermos a um "estágio inicial" de configuração cultural que nossa arte deveria ser social e primitiva e não individual e civilizada, como ocorria na Europa.

O folclore deveria ser, portanto, a matéria prima a partir da qual deveriam partir os compositores brasileiros para a confecção de sua arte. Isso porque Mário de Andrade o concebia como uma manifestação mais "pura" do inconsciente musical brasileiro. Assim: 
A própria concepção de Mário de Andrade da 'coisa folclórica' também condicionou sua definição de atitude estética. O tema do folclore teve importância central na proposta de Mário de Andrade de nacionalização da cultura. Desde os anos vinte, o ingresso da cultura brasileira na modernidade foi pensado pelo movimento modernista, e de modo destacado por Mário de Andrade, como a inserção do país no 'concerto das nações cultas'. A partir de 1924, essa inserção passou a depender da afirmação dos traços específicos de nossa cultura, pois pensava-se que apenas uma contribuição própria asseguraria ao Brasil o acesso ao contexto moderno. O retrato do Brasil que Mário de Andrade se propôs a traçar nesse momento terminava por identificar o ser nacional com a 'coisa folclórica'. No folclore estariam enraizados os traços da nacionalidade. (Moraes 1999: 80).

Contudo, os projetos modernistas de construção da cultura nacional brasileira não pregavam apenas o uso direto de temas folclóricos nas composições artísticas da época. Se, por um lado, o diálogo da cultura erudita com a popular é de suma importância, por outro, não significava uma postura simétrica entre essas contribuições. Como nos lembra Mônica Pimenta Velloso: "não se trata[va] de consagrar o popular errado do morro, mas sim de procurar resgatar o espírito de grandeza subjacente às suas manifestações" (Velloso 1987: 48-49). Sendo assim, essa matéria prima deveria ser trabalhada e refinada de forma a transformar-se em uma manifestação artística que, ao mesmo tempo que revelasse "a alma" do povo brasileiro, também pudesse estar em um nível artístico adequado para contribuir para o avanço da música universal.

Há ecos evolucionistas nessa teoria estética sobre a música brasileira, uma vez que podemos perceber a prerrogativa de que era necessário trabalhar e reformular os elementos folclóricos brasileiros. Apesar de serem considerados as fontes de onde os compositores poderiam beber do inconsciente musical brasileiro, eles também eram considerados "rudes" e "menos artísticos" do que a cultura erudita musical. Dessa forma, somente a partir do processo de reelaboração do popular é que os brasileiros poderiam construir uma verdadeira arte nacional. Além disso, Mário de Andrade estabelecia a existência de três estágios no que se refere a evolução da música nacionalista no Brasil.

Para ele, poderia ser considerada como música nacionalista de primeiro nível aquela que se dispusesse apenas a arranjar ou transcrever os temas folclóricos e populares. A importância desse tipo de composição, contudo, restringia-se ao aspecto documental, uma vez que não haveria um trabalho de criação artística envolvida nesse processo. Um pouco mais evoluído, em termos artísticos, era o segundo estágio de composição nacionalista, no qual o compositor fazia uso de citações diretas de temas folclóricos em meio às suas composições originais. Nesse tipo de música, já era possível perceber uma boa dose de artisticidade, além de ser possível vislumbrar uma forma de se efetuar a mescla entre cultura erudita e cultura popular em termos sonoros. Contudo, o estágio mais avançado de composição nacionalista referia-se ao momento no qual o compositor conseguisse compor de acordo com o inconsciente musical da nação, sem que para isso fosse necessário incorporar diretamente materiais de folclore musical. Essa música, verdadeiramente nacionalista, seria composta a partir de um processo em que nação e modernidade se mesclavam completamente, chegando mesmo a transfigurar-se em uma nova sonoridade. Era por ela que Mário de Andrade lutava. 
Entretanto, num momento de construção da arte nacional, era necessário, primeiramente, conhecer esse inconsciente musical, o que só poderia ser realizado por meio da pesquisa folclórica. Uma vez tomando consciência desse fato, Mário de Andrade preparou-se para sua segunda investida: a viagem ao Nordeste brasileiro que, apesar de ser conhecida como "a viagem de 1929”, teve início em fins de 1928, momento em que Mário já havia publicado tanto $O$ Ensaio sobre a música brasileira, quanto Macunaíma.

Se Mário de Andrade se definia como um antiviajante no início de suas aventuras etnográficas em 1927 e ainda reclamava da ausência de Tarsila do Amaral e Oswald de Andrade, que deveriam acompanhá-lo no vapor Pedro I que partiu rumo à Amazônia, em fins de 1928 o sentimento que o movia era outro. Além disso, nesse momento, Mário de Andrade já refletia sobre os métodos que deveriam ser empregados para a coleta do material sonoro que tanto buscava. Não mais acreditava em fins meramente pragmáticos - o rigor no que se refere a coleta das sonoridades brasileiras havia se tornado algo fundamental não somente para a ciência, mas também em termos artísticos.

Mário de Andrade tinha outro projeto para o material sonoro coletado no Nordeste. Ao invés de escrever um livro com fins pragmáticos que refletia sobre as necessidades sociais da música brasileira de sua época (como ocorreu em relação ao material sonoro recolhido quando de sua viagem à Amazônia, que culminou na publicação do Ensaio), ele planejava elaborar um estudo mais minucioso sobre os variados ritmos e melodias que conheceu no Nordeste, que deveria se chamar Na pancada do ganzá e que não chegou a ser concluído pelo autor. Curiosamente, esse livro deveria ser organizado em três volumes, exatamente o que ele disse não querer fazer em 1927.

A verdade é que Mário de Andrade foi aos poucos sendo capturado pela arte folclórica e popular, e, à medida que esse relacionamento se intensificava, surgiam dúvidas metodológicas e indagações "científicas". Apesar de não ter se convertido em antropólogo, como ocorreu com Maurice Leenhardt, Mário de Andrade parece ter descoberto o rendimento e a necessidade da pesquisa etnográfica em suas viagens ao Norte e ao Nordeste do Brasil. Não foi à toa, portanto, que ele incentivou, enquanto diretor do Departamento de Cultura de São Paulo, que Dina Lévi-Strauss, recém-chegada do trabalho de campo entre os Bororo e os Kadiweu, ministrasse um curso de etnografia na capital paulista em 1935. De acordo com o discurso proferido por Mário de Andrade na ocasião da aula inaugural do curso de etnografia:

Não foi ao acaso que escolhemos a Etnografia, ela se impôs. Quem quer que, mesmo diletantemente como eu, se dedique a estudos etnográficos e procure na bibliografia brasileira o conhecimento da formação cultural do nosso povo, muitas vezes desanima, pensativo, diante da facilidade, da leviandade detestável, da ausência, muitas vezes total, de orientação científica, que domina a pseudo-etnografia brasileira (...). E é principalmente nisto, na colheita da documentação popular que a enorme maioria dos nossos livros etnográficos é falsa (...). Colher, colher 
cientificamente nossos costumes, nossas tradições populares, nossos caracteres raciais, esta deve ser a palavra de ordem dos nossos estudos etnográficos; e num sentido eminentemente prático vão se orientar os trabalhos deste Curso de Etnografia (Mário de Andrade apud Catálogo da Sociedade de Etnografia e Folclore, 1993, p. 05).

Também não é mera coincidência que a criação da Sociedade de Etnografia tenha ocorrido em 1936, novamente a partir de uma iniciativa de Mário de Andrade. Tanto quanto o curso de Etnografia ministrado por Dina Lévi-Strauss, um ano antes, ela era necessária para a construção da arte brasileira, já que nesse momento de construção nacional, a experiência etnográfica se impunha como algo imprescindível para o estabelecimento da arte moderna no Brasil. 


\section{NOTAS}

1 A Sociedade de Etnografia e Folclore foi criada em 1936 e foi, em parte, um desdobramento do curso de etnografia ministrado por Dina-Lévi-Strauss e que foi financiado pelo Departamento de Cultura de São Paulo, por iniciativa de Mário de Andrade (na época diretor da instituição). Segundo a antropóloga Marta Amoroso (1993), além de incentivar a realização de novas pesquisas etnográficas em meio a população brasileira, a "Sociedade de Etnografia e Folclore" também tinha fins museológicos, na medida em que Mário de Andrade teria trabalhado para salvar objetos cerimoniais populares, sobretudo do candomblé, das fogueiras a que estavam destinados. Afirmando a importância desses objetos para a ciência etnográfica, Mário escreveu ao Departamento de polícia, requisitando a guarda de tais peças.

2 Várias histórias contadas por Villa-Lobos como episódios por ele vivenciados foram retirados do famoso relato de Hans Staden sobre sua experiência entre os tupinambás, no início do século XVI. Sobretudo à crítica francesa, Villa-Lobos teria contado que quase foi devorado por canibais da Amazônia e que, por ter vivido entre os índios, ele seria um exímio conhecedor da cultura brasileira. Contudo, para o presente estudo não se faz fundamental discutir se Villa-Lobos realmente esteve entre os índios ou se ele apenas se aproveitou do relato de Staden para constituir sua autoridade "etnográfica". O que de fato importa é o quanto essa retórica é de fato importante para a conformação do artista brasileiro à essa época. Vale ressaltar que Villa-Lobos começa a fazer um relativo sucesso em Paris somente após difundir suas histórias sobre a "exótica" população amazônica .

3 Na página 51 do seu livro O Turista aprendiz, Mário de Andrade escreveu: "Não fui feito para viajar, bolas!1Estou sorrindo, mas por dentro de mim vai um arrependimento assombroso, cor de incesto. Entro na cabina, agora é tarde, já parti, nem posso me arrepender". As declarações iniciais demonstram como essa viagem se impunha para ele mais como uma necessidade do que como um desejo.

4 O fato de Villa-Lobos ser escolhido por Graça Aranha para representar a música moderna na Semana de Arte Moderna de 1922 é significativo, na medida em que atesta o "atraso" paulista frente às novidades do recente modernismo francês. O compositor carioca foi a São Paulo para apresentar músicas que foram compostas, anteriormente ao evento; algumas delas, inclusive, já haviam sido estreadas no Rio de Janeiro em 1921.

5 Para mais informações sobre o relacionamento de Heitor Villa-Lobos e Mário de Andrade e seus desdobramentos na teoria estéticomusical marioandradiana, consultar: TONI (1987). Acerca do projeto pedagógico musical desenvolvido por Heitor Villa-Lobos a partir de 1932, ver SOUZA (2006).

6 Toni (1990) diferencia O Ensaio sobre a música brasileira das outras produções com objetivo musical de Mário de Andrade, pois somente esse livro teria tido o objetivo de sintetizar uma estética almejada da música nacionalista, enquanto os outros títulos poderiam ser considerados em sua maioria como compêndios de compilação folclórica. Neles, contudo, o trabalho musicológico de coleta e transcrição de exemplos musicais foi muito mais intenso.

7 Esse título foi escrito por Mário para um público diferente: seus alunos do curso de História da Música do Conservatório Dramático Musical de São Paulo e obedece, por esse mesmo motivo, a fins didáticos. Segundo Toni (1990) não havia na época nenhum livro de História da Música editado no Brasil.

8 Trecho de O Ensaio sobre a música brasileira, primeiramente publicado em 1928. A edição consultada para a elaboração desse artigo é de 1972. 
AMOROSO, M. R. 1993. Sociedade de Etnografia e Folclore (1936-1939). Modernismo e Antropologia. SEF. Sociedade de Etnografia e Folclore [catálogo]/ Discoteca Oneyda Alvarenga; coordenação Maria Regina A. Davidoff e Elizabete H. Shimabukuro et al. São Paulo, CCSP, São Paulo: 65-71.

ANDRADE, M. [1928] 1972. Ensaio sobre a Música Brasileira. São Paulo: Martins.

. [1929] 1988. Pequena História da Música. São Paulo: Martins.

. [1943] 2002. O Turista Aprendiz. Belo Horizonte: Itatiaia.

CANDIDO, A. 1983. "A revolução de 1930 e a cultura". In A Educação pela noite e outros ensaios. Petrópolis: Vozes.

CATÁLOGO DA SOCIEDADE DE ETNOGRAFIA E FOLCLORE. 1993. Discoteca Oneyda Alvarenga. Centro Cultural São Paulo.

CLIFFORD, J. 1982. Person and the myth. Maurice Leenhardt in a Melanesian world. Berkely and Los Angeles: University of California press.

LOPEZ, T. A. 1996. Mariodeandradiando. São Paulo: Hucitec.

. 2002. "Viagens Etnográficas de Mário de Andrade". In M. Andrade [1943]. O Turista Aprendiz. Belo Horizonte: Itatiaia. . 2002 “A Bordo do Diário". In M. Andrade [1943]. O Turista Aprendiz. Belo Horizonte: Itatiaia.

MICELI, S. 1979. Intelectuais e classe dirigente no Brasil (1920-1945). Rio de Janeiro: Guanabara.

MORAES, E. J. 1999. Limites do Moderno: o pensamento estético de Mário de Andrade. Rio de Janeiro: Relume Dumará. SIMÕES JR , G. 1998. Palavra Peregrina. São Paulo: Edusp.

SOUZA, C. D. de. 2006. O Brasil em pauta: Heitor Villa-Lobos e o canto orfeônico. Dissertação de mestrado defendida no Programa de Pós-Graduação em Antropologia Social da Universidade de São Paulo.

TONI, F. C. 1987. Mário de Andrade e Villa-Lobos. São Paulo: Centro cultural São Paulo.

1990. O Pensamento Musical de Mário de Andrade. São Paulo: Tese de Doutoramento apresentada ao Programa de Pós-Graduação em Artes da ECA/USP.

TRAVASSOS, Elisabeth. 1997. Os Mandarins Milagrosos: música e etnografia em Mário de Andrade e Bela Bartók. Rio de Janeiro: Funarte/Jorge Zahar editor.

. 2002. Música e modernismo no Brasil. Rio de Janeiro: Jorge Zahar editor.

VELLOSO, M. P. 1987. Os Intelectuais e a Política Cultural do Estado Novo. Rio de Janeiro: CPDOC. 


\section{Mário de Andrade: Turista aprendiz da musicalidade brasileira}

\section{RESUMO}

O mais importante teórico acerca da música moderna que se desenvolve no Brasil foi, sem dúvida, Mário de Andrade, com um grande número de trabalhos sobre música publicados, além de seus poemas e romances com cadência musical. Este artigo descreve como a viagem que Mário de Andrade faz à Amazônia, em 1927, consegue alterar os códigos de musicalidade compreensíveis à audição do autor, e com isso, acaba influenciando toda a concepção de música nacional desenvolvida no Modernismo brasileiro. Entendendo a diversidade da linguagem sonora, Mário de Andrade fixa em seu diário de viagens, publicado postumamente sob o título de "Turista Aprendiz", como se deu o processo de seu descentramento estético-musical, sobretudo a partir de dois relatos evidentemente ficcionais presentes no livro. $\mathrm{O}$ uso do surrealismo e do non sense são aqui imprescindíveis para se obter a real noção da dificuldade encontrada pelo escritor em afinar-se a outras musicalidades, inerentes ao Brasil e à sonoridade brasileira. Grande parte dessas reflexões, baseadas na experiência do viajante, já se encontram presentes no livro musical de maior envergadura de Mário de Andrade: "O Ensaio sobre a música brasileira", publicado originalmente em 1928, concebido como um dos textos clássicos para a Musicologia Brasileira. Além disso, é possível vislumbrar, por meio de sua trajetória como turista e musicólogo aprendiz, o intrínseco relacionamento que é estabelecido entre arte e etnografia para a configuração da arte moderna no Brasil.

PALAVRAS-CHAVE: modernismo; música; folclore; viagem; etnografia.

\section{Mario de Andrade: Apprentice tourist of Brazilian Musicality}

\section{ABSTRACT}

The most important thinker about modern music in Brazil was Mario de Andrade. This article describes how his travel to Amazonia, in 1927, was responsible for changing the author's musical codes, influencing the conceptions of national music developed in Brazilian Modernism. In The Apprendice Tourist, travel diary published after his death, Mario de Andrade describes, through two fictional narratives, his process of musical and aesthetical decentralization. The use of the surrealism and the non-sense are important tips to discover the difficulty found by the writer in tuning himself to the musicalities inherent to Brazil to the Brazilian sonority as a whole. It is important to mention that great part of those thoughts can be founded in his book "The Essay of Brazilian Music", published in 1928. Besides, it is possible to verify, through his trajectory as an apprentice tourist and musicologist, the close relation between art and ethnography to the Modern art in Brazil.

KEYWORDS: modernism; music; folk culture; travels and ethnography. 